\title{
ANALISA FAKTOR PENGHAMBAT PENERAPAN BUILDING INFORMATION MODELING DALAM PROYEK KONSTRUKSI
}

\author{
(The Obstacle Factors in The Implementation of BIM in Construction Projects)
}

\author{
Handika Rizky Hutama ${ }^{1}$, Jane Sekarsari ${ }^{1}$ \\ ${ }^{1}$ Program Studi Magister Teknik Sipil Universitas Trisakti, \\ E-mail: handikarizkyhutama@yahoo.co.id
}

\begin{abstract}
ABSTRAK
Pemanfaatan teknologi informasi menjadi salah satu strategi untuk meningkatkan kinerja dan daya saing perusahaan dalam menangani proyek konstruksi secara efektif dan efisien. Building Information Modeling (BIM) adalah sistem informasi yang memproses input menjadi informasi dalam bentuk pemodelan bangunan sebagai alat bantu dalam proses pengambilan keputusan dalam setiap tahapan proyek konstruksi. BIM dalam proyek konstruksi menghadapi berbagai hambatan akibatnya manfaat penerapannya tidak optimal. Dari penelitian sebelumnya belum terdapat adanya studi analisa faktor penghambat penerapan BIM pada proyek konstruksi di Indonesia. Penelitian ini bertujuan mendapatkan faktor-faktor dan faktor utama penghambat penerapan BIM dalam proyek konstruksi serta bermanfaat bagi perusahaan dalam meningkatkan penerapannya dalam proyek konstruksi yang ditanganinya. Metode penelitian ini dilakukan dengan metode statistik deskriptif, analisa korelasi dan analisa faktor. Teknik pengumpulan data dengan mengunakan kuisioner dan wawancara. Kuesioner disebarkan kepada responden yaitu pengguna BIM pada proyek konstruksi sejumlah 40 responden. Hasil penelitian menunjukan faktor utama penghambat penerapan BIM dalam proyek konstruksi yaitu kurangnya partisipasi manajemen dalam memberikan motivasi, pelatihan, dan pengawasan yang ditetapkan perusahaan.
\end{abstract}

Kata Kunci: faktor penghambat, BIM, implementasi, proyek konstruksi

\begin{abstract}
Utilization of information technology is one of the strategies to improve the performance and competitiveness of enterprises in handling construction projects effectively and efficiently. Building Information Modeling (BIM) is an information system that processes input into information in the form of building modeling as a tool in the decision making process in each stage of the construction project. BIM in construction projects face many obstacles as a result the benefits of its application has not optimal. There is a lack of prior research about analysis of the obstacle factors in the adoption of BIM in construction projects in Indonesia. This study aims to provide information factors and the main obstacle factors the application of BIM in construction projects that benefit the company in improving its application in construction projects. This study was conducted using descriptive statistics, correlation analysis and factor analysis. Data collection techniques by using questionnaires and interviews. The quesioners were distributed to the respondents, the BIM user in construction projects as much as of 40 respondents. The results show that main obstacle factor the application of BIM in construction projects is the lack of participation of management in providing the motivation, training, and supervision as targeted by the company.
\end{abstract}

Keywords: BIM , obstacle factors, implementation, construction projects 


\section{PENDAHULUAN}

Proyek konstruksi dengan tingkat kompleksitas yang tinggi harus memiliki manajemen yang baik dalam mengelola sumber daya - sumber daya untuk mencapai tujuan/sasaran yang telah direncanakan secara efisien dan efektif dengan memperhatikan kesempatan yang ada serta memperhitungkan risiko/hambatan yang dihadapi. Adapun sumber daya yang sering disebutkan dalam proyek konstruksi sebagai input hanya 5M (Man, Machine, Method, Material, dan Money) tanpa menyebut informasi, yang justru merupakan masukan yang penting (Sekarsari, Jane 2014). Informasi adalah fakta, kejadian, statistik atau bentuk data lainnya yang dapat dipahami mengalami proses transformasi dan mempunyai arti, bernilai atau bermanfaat bagi seseorang untuk keperluan/pekerjaan tertentu. Data pada umumnya harus diolah terlebih dahulu sehingga menjadi informasi yang dapat dipahami dan bermanfaat atau lebih bermanfaat. Informasi merupakan salah satu sumber daya yang diperlukan dalam pengambilan keputusan. Untuk mempercepat, mempermudah, mendapatkan informasi diperlukan teknologi informasi. Menurut Utomo (2000), menyebutkan bahwa dewasa ini teknologi informasi menjadi salah satu strategi bagi manajer untuk meningkatkan kinerja dan daya saing perusahaan. Teknologi informasi dalam manajemen proyek yang dimaksud adalah Building Information Modeling (BIM). BIM adalah sistem informasi untuk mengelola sumber daya informasi yang memproses data/input menjadi informasi dalam bentuk pemodelan bangunan untuk diberikan kepada pelaku proyek dalam aktivitas konstruksi sebagai dasar dalam pengambilan keputusan, proses menghasilkan dan mengelola data bangunan dalam siklus proyeknya. BIM dapat menampilkan informasi-informasi menggunakan tiga dimensi secara real-time, software bangunan pemodelan dinamis untuk meningkatkan produktivitas dalam membangun desain dan konstruksi. Proses ini menghasilkan Informasi Model Bangunan yang meliputi bangunan geometri, hubungan spatial, informasi geografis, dan jumlah dan sifat dari komponen bangunan. BIM salah satu teknologi di bidang AEC (Arsitekture, Engineering dan Construction) yang mampu mensimulasikan seluruh informasi di dalam proyek pembangunan ke dalam model 3 dimensi. Dengan menerapkan metode BIM, baik developer, konsultan maupun kontraktor mampu menghemat waktu pengerjaan, biaya yang dikeluarkan serta tenaga kerja yang dibutuhkan.

Menurut Bicara BIM (2016) penggunaan BIM di Indonesia dirasakan belum maksimal dengan perkembangan yang semakin stagnan . Penggunaan BIM sendiri di Indonesia masih hanya sebatas menjawab persoalan bagaimana mengefisiensikan kebutuhan tenaga kerja, waktu dan uang. Dalam penerapan BIM , manajer menghadapi tantangan berat untuk menerapkannya agar dapat mendukung sasaran-sasaran organisasi yang bersangkutan. Sistem informasi dan organisasi akan sangat mempengaruhi. Disatu sisi sistem informasi harus disinkronkan dengan organiasi agar kebutuhan informasi dari organisasi terpenuhi, disisi lain organiasi harus terbuka terhadap pengaruh-pengaruh dari sistem informasi agar mendapatkan keuntungan maksimal dari teknologi baru yang dipakai. Karena sistem informasi potensial merubah struktur, budaya , politik, dan pola kerja organisasi, maka sering timbul hambatan pada saat penerapannya.

Penelitian faktor penghambat penerapan BIM telah banyak dilakukan oleh peneliti-peneliti terdahulu diluar negeri, tetapi di Indonesia penulis belum menemukan penelitian tersebut. Penerapan BIM masih menghadapi tantangan berat dengan berbagai faktor-faktor penghambat. Menurut Boya Ji, Zhenqiang Qi, and Zhanyong Jin I (2014) masalah penerapan BIM dibagi dalam 3 aspek yaitu teknologi, organisasi, dan personal. Menurut Challenges AEC industry BIM Advantages BIM Solutions BIM Management in BIM Implementation (2013) faktor penghambat implementasi BIM yaitu sistem yang kompleks, kurang kompetensi dan pengetahuan BIM (keahlian), resisten terhadap perubahan ,budaya kerja, informasi Manajemen hambatan dalam mengelola sumber daya dan informasi, keterlibatan pelaku proyek yang kurang ,harga yang tinggi, mengubah proses kerja dalam organisasi, dan perusahaan khawatir biaya yang mengikuti setelah pelaksanaan $B I M$, terbatas nya transfer data karena ketidakcocokan sistem antar pelaku proyek, pengguna BIM diaplikasikan untuk pekerjaan yang berisiko akibatnya pekerjaan yang tidak berisiko tidak di terapkan (tidak seluruh pekerjaan diterapkan), kurang pengalaman, BIM efektif untuk pengadaan konstruksi Desain and Build atau Construction Management and Risk tetapi masih banyak yang menggunakan Desain Bid-Build proyek, tingginya investasi, keberhasilan rendah, sumber daya manusia yang tidak terampil ,serta kurang dukungan dari perusahaan, masalah dalam pertukaran data, kurangnya efisiensi penggunaan hardware.

Penelitian ini dilakukan dari sudut pandang yang berbeda yaitu untuk menganalisis faktor faktor penghambat penerapan BIM sehingga didapatkan informasi faktor-faktor dan faktor utama yang mempengaruhi terhambatnya penerapan dalam proyek konstruksi sehingga dapat ditemukan solusi yang tepat mengatasi faktor penghambat yang utama. Selain itu penelitian ini dapat bermanfaat bagi perusahaan dalam usaha meningkatkan dan pengembangan 
penerapan BIM dalam proyek konstruksi yang ditanganinya.

\section{METODOLOGI}

Untuk mengetahui faktor-faktor penghambat dalam penerapan BIM suatu proyek konstruksi disusunlah metodologi penelitian. Alur penelitian dapat dilihat pada Gambar 1 berikut ini.

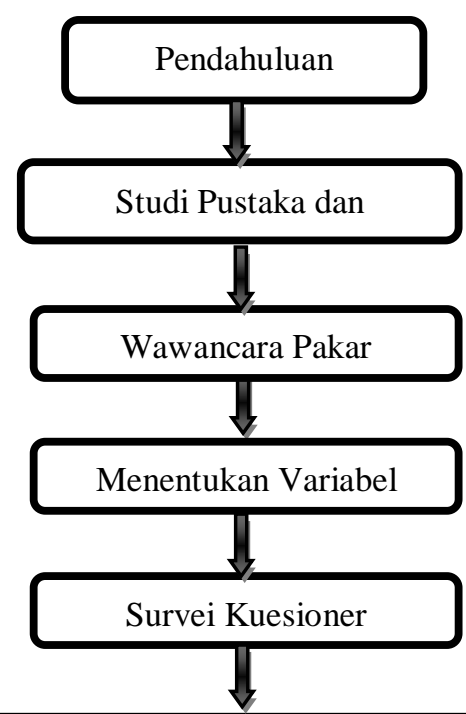

Pengumpulan dan Tabulasi Data Kuisioner

Analisis Data : (Software SPSS ver.20)

1. Uji Validitas dan Realibilitas Data

2. Analisa Deskriptif Data

3. Analisa Faktor :

a. Analisis Kaiser Mayer Olkin dan

Barlettest of sparetcity

b. Analisis Matrik Image Correlation

c. Analisis Total Variance Explained
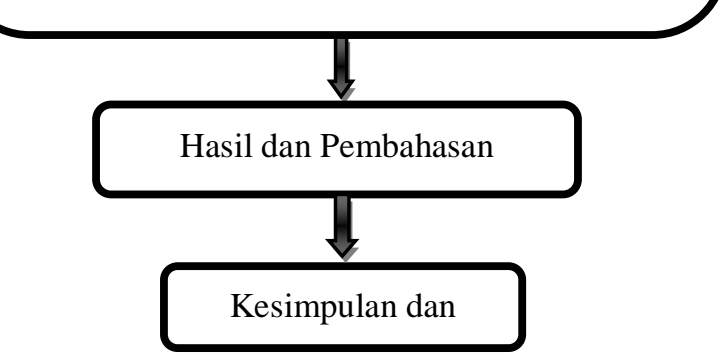

Gambar 1. Gambar Alur Penelitian

Penelitian dilakukan dengan 4 tahap:

a. Tahap pertama

Melakukan studi pustaka dan penelitian terdahulu untuk mengetahui teori-teori yang berhubungan dengan faktor penghambat penerapan BIM, mencari metode penelitian, teknik analisa data dan sebagainya yang berhubungan dengan penelitian ini. Hasil telaah studi pustaka dan penelitian terdahulu dapat dilihat pada tabel 1 sebagai berikut:

Faktor faktor Penghambat dikelompokkan dalam Faktor Penghambat Organisasi, Faktor Penghambat Personal dan Faktor Penghambat Teknologi

Tabel 1. Tahap Pertama : Hasil Telah Studi Pustaka dan Penelitian Tentang BIM

\begin{tabular}{ll}
\hline No & \multicolumn{1}{c}{ Faktor Penghambat } \\
\hline \multicolumn{1}{c}{ Organisasi } \\
\hline 1 & $\begin{array}{l}\text { Kurangnya kemampuan sumber daya } \\
\text { manusia yang ditempatkan di proyek (Tonny } \\
\text { Dwihanata Prayogo,2000) }\end{array}$ \\
\hline & $\begin{array}{l}\text { Kebiasaan-kebiasaan kerja sistem lama } \\
\text { yang ada di perusahaan (budaya organisasi } \\
\text { perusahaan) (Yosi Agustiawan, 2011; Boya } \\
\text { Ji, Zhenqiang Qi, and Zhanyong Jin,2014) }\end{array}$ \\
\hline 3 Tidak Jelasnya target/sasaran BIM yang \\
ditetapkan perusahaan (Prio Budiono, 2013)
\end{tabular}


Tidak menerapkan BIM manajemen proyek karena kontaktor dan perencana tidak mengunakan (Prio Budiono, 2013; Boya Ji, Zhenqiang Qi, and Zhanyong Jin, 2014)

Rencana mutu yang belum jelas sehingga

13 sulit untuk diaplikasikan dalam proyek (Prio Budiono, 2013)

Kompleksitas pekerjaan ,menjadi beban

14 bagi pengguna BIM manajemen proyek (Tonny Dwihanata Prayogo,2000)

15 Prosedur operasional BIM yang kompleks (Prio Budiono, 2013)

BIM efektif untuk Desain Build atau CM-

16 Risk tetapi masih banyak yang menggunakan Design Bid Build pada proyek (Saeed Reza Mohades, 2014)

Tidak Konsisten manajerial dalam

17 menerapkan BIM manajemen proyek sesuai SOP (Prio Budiono, 2013)

Penerapan software manajemen proyek

18 SOP yang tidak sepenuhnya (Prio Budiono, 2013)

Kurangnya pengawasan/audit dalam

19 penerapan BIM manajemen proyek (Prio Budiono, 2013)

BIM memiliki popularitas yang rendah

20 (Boya Ji, Zhenqiang Qi, and Zhanyong Jin, 2014)

Biaya investasi besar (Tonny Dwihanata Prayogo, 2000; Boya Ji, Zhenqiang Qi, and

21 Zhanyong Jin, 2014; Darius Migilinskas, Vladimir Popov, Virgaudas Juocevicius, Leonas ustinovichius, 2013)

Belum adanya peraturan/standar BIM di Indonesia

22 (https://forums.autodesk.com/t5/komunitasindonesia/materi-autodesk-cad-camp2015-bandung/ba-p/5612144)

Belum jelasnya road map dari pemerintah selaku regulator untuk sosialisasi BIM

23 (https://forums.autodesk.com/t5/komunitasindonesia/materi-autodesk-cad-camp2015-bandung/ba-p/5612144)

Penerapan BIM di Indonesia masih dilakukan secara sporadis oleh masingmasing aktor tanpa ada lembaga atau organisasi yang saling menghubungkan sehingga tidak ada ketercapaian lain yang

24 ditargetkan dari penggunaan BIM https://medium.com/bicara-

bim/mempelajari-penerapan-buildinginformation-modeling-bim-di-amerikaserikat-acafd7274696\#.fexp55ywr

\section{Personal}

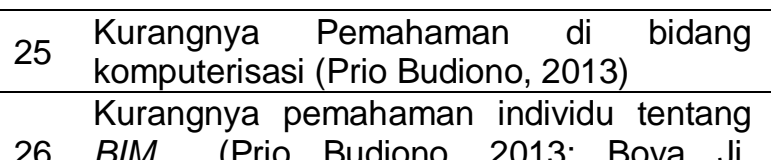

26 BIM (Prio Budiono, 2013; Boya Ji, Zhenqiang Qi, and Zhanyong Jin, 2014)

27 Etika individu yang kurang dalam penggunaan perangkat BIM (Jane, 2014)
Penggunaan BIM manajemen proyek menurunkan produktivitas dalam melaksanakan pekerjaan (Tonny Dwihanata Prayogo,2000)

Usia membuat kurangnya maksimalnya

29 penggunaan BIM manajemen proyek. (lemahnya dayaa nalar dan ingat) (Tonny Dwihanata Prayogo,2000)

Kurangnya BIM sebagai dasar dalam efisiensi pelaksanaan (Boya Ji, Zhenqiang

$30 \mathrm{Qi}$, and Zhanyong Jin , 2014 ; Darius Migilinskas, Vladimir Popov, Virgaudas Juocevicius, Leonas ustinovichius, 2013)

Pengembangan BIM belum sempurna

31 (Boya Ji, Zhenqiang Qi, and Zhanyong Jin, 2014)

\section{Teknologi}

Kesulitan dalam sinergi desain (Kurang memenuhi kebutuhan pengguna/user), Terbatasnya transfer data karena ketidakcocokan sistem antar pelaku proyek.

32 (Boya Ji, Zhenqiang Qi, and Zhanyong Jin, 2014; Darius Migilinskas, Vladimir Popov, Virgaudas Juocevicius, Leonas ustinovichius ,2013)

\begin{tabular}{|c|c|}
\hline 33 & $\begin{array}{l}\text { Kejahatan komputer (hacker dan virus) } \\
\text { karena software memiliki kelemahan } \\
\text { (Tonny Dwihanata Prayogo,2000) }\end{array}$ \\
\hline 34 & $\begin{array}{l}\text { Kesulitan sistem pada software BIM } \\
\text { (Saeed Reza Mohades, 2014) }\end{array}$ \\
\hline 35 & $\begin{array}{l}\text { Masalah dalam pertukaran data (S } \\
\text { Reza Mohades, 2014) }\end{array}$ \\
\hline
\end{tabular}

b. Tahap Kedua

Wawancara pakar yaitu wawancara kepada untuk dikonsultasikan kepada pakar BIM yang memiliki pengalaman menggunakan BIM pada proyek konstruksi untuk memvalidasi dan klarifikasi hasil kajian pustaka dan penelitian terdahulu pada tahap 1. Kriteria pakar pada penelitian tahap kedua yaitu memiliki pengalaman lebih dari 15 tahun di dunia konstruksi dengan pendidikan terakhir S1 dan minimal berpengalaman 5 tahun. Para pakar tersebut diminta persetujuan dan komentarnya untuk menyarankan apakah variabel tersebut masih memerlukan tambahan atau pengurangan terhadap indikatornya dan apakah variabel penghambat yang diberikan penulisdari studi pustaka sesuai dengan penerapan BIM dalam proyek konstruksi di Indonesia. Hasil wawancara pakar disusun menjadi kuisioner responden, yang tentunya akan mengalami banyak perubahan sesuai komentar dari para pakar tersebut. Hasil wawancara pakar (validasi dan klarifikasi) tahap kedua pada tabel 2 berikut ini

Tabel 2. Hasil Wawancara Pakar (Validasi dan Klarifikasi) Tahap Kedua 


\begin{tabular}{|c|l|}
\hline No & \multicolumn{2}{|c|}{ Faktor Penghambat } \\
\hline 1 & $\begin{array}{l}\text { Organisasi } \\
\text { Kurangnya kemampuan sumber daya } \\
\text { manusia yang ditempatkan di proyek }\end{array}$ \\
\hline 2 & $\begin{array}{l}\text { Kebiasaan-kebiasaan kerja sistem } \\
\text { lama yang ada di perusahaan (budaya } \\
\text { organisasi perusahaan) }\end{array}$ \\
\hline 3 & $\begin{array}{l}\text { Kurangnya Motivasi individu dalam } \\
\text { mengembangkan BIM. (cara tradisional } \\
\text { dalam melakukan pekerjaan) }\end{array}$ \\
\hline 4 & $\begin{array}{l}\text { Kurangnya Tanggung jawab individu } \\
\text { terhadap hasil pekerjaan BIM,. } \\
\text { (Kurangnya kemampuan teknis } \\
\text { pemanfaatan BIM) }\end{array}$ \\
\hline 5 & $\begin{array}{l}\text { Perangkat keras dan perangkat lunak } \\
\text { komputer pada proyek sulit } \\
\text { dioperasikan }\end{array}$ \\
\hline 6 & $\begin{array}{l}\text { Kurangnya Fasilitas Komputer yang } \\
\text { memenuhi spesifikasi (Perangkat } \\
\text { keras dan perangkat lunak komputer } \\
\text { )pada proyek. }\end{array}$ \\
\hline 7 & $\begin{array}{l}\text { Perangkat keras dan perangkat lunak } \\
\text { komputer pada proyek tidak memiliki } \\
\text { kemampuan proses yang tinggi. }\end{array}$ \\
\hline 8 & $\begin{array}{l}\text { Kurangnya partisipasi manajemen } \\
\text { dalam memberikan motivasi, pelatihan, } \\
\text { dan pengawasan }\end{array}$ \\
\hline 9 & $\begin{array}{l}\text { Kurangnya peraturan/standar prosedur } \\
\text { operasional BIM yang ditetapkan } \\
\text { perusahaan. }\end{array}$ \\
\hline 10 & $\begin{array}{l}\text { Tidak menerapkan BIM manajemen } \\
\text { proyek karena kontaktor dan } \\
\text { perencana tidak mengunakan. }\end{array}$ \\
\hline 11 & $\begin{array}{l}\text { Tidak Jelasnya target/sasaran BIM } \\
\text { yang ditetapkan perusahaan. }\end{array}$ \\
\hline 12 & $\begin{array}{l}\text { Rencana mutu yang belum jelas } \\
\text { sehingga sulit untuk diaplikasikan } \\
\text { dalam proyek }\end{array}$ \\
\hline 13 & $\begin{array}{l}\text { Kompleksitas pekerjaan menjadi } \\
\text { beban bagi pengguna BIM } \\
\text { manajemen proyek. }\end{array}$ \\
\hline 14 & $\begin{array}{l}\text { Prosedur operasional BIM yang } \\
\text { kompleks. }\end{array}$ \\
\hline 15 & $\begin{array}{l}\text { Tidak Konsisten manajerial dalam } \\
\text { menerapkan BIM manajemen proyek }\end{array}$ \\
\hline
\end{tabular}

Hasil wawancara pakar diperoleh 27 variabel dari 35 variabel pada penelitian tahap pertama. Hasil tersebut dijadikan variabel penelitian sebagai pertanyaan pada tahap ketiga penelitian yaitu survei kuisioner.

\section{c.Tahap Ketiga}

Tahap ketiga dilaksanakan survei dengan penyebaran kuisioner kepada 40 responden pada beberapa proyek di Jakarta dan sekitarnya. Kriteria sampel responden

memiliki kesempatan terlibat langsung penerapan $B I M$ sesuai dengan jabatannya di perusahaan, dengan waktu operasional ditetapkan selama minimal 3 tahun, memiliki kemauan dan kemampuan merespon penerapan BIM sesuai dengan jabatannya di proyek, serta dibedakan berdasarkan gender, umur, pendidikan,dan pengalaman kerja. Skala ukuran yang sering digunakan dalam penelitian adalah skala liekert seperti pada Tabel 3 berikut ini :

Tabel 3. Angka skor tingkat kepentingan dan tingkat pengaruh

\begin{tabular}{|l|l|l|}
\hline $\begin{array}{l}\text { Tingkat } \\
\text { kepentingan }\end{array}$ & Skor & Tingkat pengaruh \\
\hline $\begin{array}{l}\text { Sangat } \\
\text { setuju }\end{array}$ & 5 & $\begin{array}{l}\text { Sangat } \\
\text { Mempengaruhi }\end{array}$ \\
\hline Setuju & 4 & Mempengaruhi \\
\hline Ragu-ragu & 3 & $\begin{array}{l}\text { Cukup } \\
\text { Mempengaruhi }\end{array}$ \\
\hline Tidak Setuju & 2 & $\begin{array}{l}\text { Kurang } \\
\text { Mempengaruhi }\end{array}$ \\
\hline $\begin{array}{l}\text { Sangat } \\
\text { Tidak Setuju }\end{array}$ & 1 & $\begin{array}{l}\text { Tidak } \\
\text { Mempengaruhi }\end{array}$ \\
\hline
\end{tabular}

Pertanyaan kuisioner dalam skala likert, responden menentukan tingkat persetujuan mereka terhadap suatu peryataan dengan memilih salah satu dari pilihan yang tersedia. Setelah dilakukan survei kuisioner didapatkan data kuisioner yang akan dianalisa pada penelitian tahap keempat.

\section{d. Tahap Keempat}

Data hasil pentabulasian kemudian digunakan sebagai input data ke dalam program SPSS ( Statistical Program For Social Science) untuk dilakukan analisis sebagai berikut :

1. Uji Validitas dan Reliabilitas Data

Validitas adalah ketepatan atau kecermatan suatu instrument dalam mengukur apa yang diukur. Teknik pengujian menggunakan Pearson Correlation. Uji Reliabilitas digunakan untuk mengetahui konsitensi alat ukur, apakah alat ukur yang dapat digunakan dapat diandalkan dan tetap konsisten jika pengukuran tersebut diulang. Di dalam penelitian ini akan digunakan metode Cronbach's Alpha.

2. Interpretasi Statistik Deskriptif

Dari hasil analisis deskriptif yang telah dilakukan, dapat diketahui karakteristik data yang diperoleh.

3. Analisa Faktor

Analisa faktor merupakan suatu analisis statistik yang berfungsi untuk mereduksi atau meringkas beberapa variabel yang saling independen menjadi sedikit variabel. Tahapan analisa faktor sebagai berikut : 
a. Analisis Kaiser Mayer Olkin (KMO) dan Barlettest of sparetcity

Analisis Kaiser Mayer Olkin (KMO) dan Barlettest of sparetcity merupakan uji statistik yang digunakan untuk menguji ada tidaknya korelasi antar variabel dalam populasi.

b. Analisis Matrik Image Correlation Selanjutnya untuk melihat korelasi antar variabel independen dapat diperhatikan tabel Anti Image Matrices.

c. Analisis Total Variance Explained Analisis Total Variance Explained menunjukkan besarnya persentase keragaman total yang mampu diterangkan oleh keragaman faktor faktor yang terbentuk.

d. Analisis Rotated Component tabel Matrik

Pada proses rotasi ini biasanya masih terdapat variabel-variabel yang belum mempunyai posisi yang jelas dalam suatu kelompok atau grup faktor. Metode rotasi yang digunakan adalah metode Varimax.

\section{HASIL DAN PEMBAHASAN}

Hasil analisa data sebagai berikut :

1. Uji Validitas dan Reliabilitas Data Hasil pengujian uji validitas menyatakan semua variabel valid/tepat. Hasil dari pengujian reliabilitas data yang dilakukan sebaran data memenuhi kriteria reliabilitas/tetap.

2. Interpretasi Statistik Deskriptif

Dari hasil analisis deskriptif yang telah dilakukan, dapat diketahui karakteristik data yang diperoleh. Dari data yang telah dianalisis diketahui bahwa rata-rata responden merespon setiap variabel penghambat penerapan BIM pada tingkat pengaruh kurang mempengaruhi (skala 2) sampai dengan tingkat mempengaruhi (skala 4).

3. Analisa Faktor

Hasil analisa faktor sebagai berikut :

a. Analisis Kaiser Mayer Olkin (KMO) dan Barlettest of sparetcity

Hasil dari uji KMO dan Bartlett's Test of Shpericity yang telah dilaksanakan menyatakan bahwa data dapat dianalisis dengan analisis faktor.

b. Analisis Matrik Image Correlation Hasil analisis Matrik Anti Image Correlation memenuhi syarat analisis selanjutnya dapat dilakukan dan data dapat dianalisis dengan analisis faktor.

c. Analisis Total Variance Explained Hasil analisis Total Variance Explained, diketahui bahwa variabel-variabel penghambat penerapan BIM dikelompokan menjadi 7 faktor utama dengan hasil Total Variance merupakan kumulatif untuk semua komponen (faktor) berada pada tingkat memuaskan. Sedangkan dari tabel dan grafik eigenvalue menunjukkan terdapat 7 komponen atau faktor.

d. Analisis Rotated Component tabel Matrik

Hasil analisis diatas diketahui bahwa seluruh variabel yang dianalisis membentuk 7 komponen dan yang tereduksi valid.

Dari hasil analisis faktor variabel-variabel tersebut membentuk 7 komponen, adanya pengelompokan menjadi 7 komponen variabel ini disebabkan mempunyai sifat/karakteristik data yang identik antara variabel satu dan lainnya. Selanjutnya dilakukan rangking/peringkat dari 7 komponen tersebut untuk menunjukan tingkat pengaruh variabel terhadap penghambat penerapan BIM. Setelah dilakukan rangking pada ke 7 komponen tersebut dilakukan pemberian nama sesuai dengan faktor penghambat penerapan BIM yang terdapat pada kelompok masing -masing. Dari rangking/peringkat dari 7 komponen variabel, diketahui bahwa peringkat 1 yaitu variabel-variabel yang berada pada komponen 1 (faktor1) (Pengembangan BIM (tim proyek)) terdiri dari 6 faktor yaitu : X2 Kurangnya partisipasi manajemen dalam memberikan motivasi, pelatihan, dan pengawasan, X4 Tidak Jelasnya Target/sasaran BIM yang ditetapkan perusahaan, X8 Tidak menerapkan BIM manajemen proyek karena kontraktor dan perencana tidak mengunakan, X9 rencanamutu yang belum jelas sehingga sulit untuk diaplikasikan dalam proyek, X18 Kompleksitas pekerjaan ,menjadi beban bagi pengguna BIM manajemen proyek, X21 Prosedur operasional $B I M$ yang kompleks.

\section{KESIMPULAN}

Berdasarkan hasil penelitian dan pembahasan, maka penulis dapat mengambil kesimpulan bahwa faktor utama penghambat penerapan BIM pada proyek konstruksi gedung adalah kurangnya partisipasi manajemen dalam memberikan motivasi, pelatihan, dan pengawasan. Motivasi adalah salah satu upaya untuk menjadikan perusahaan itu bisa berkembang dan maju. Dengan motivasi para karyawan akan memberikan kontribusinya sesuai dengan kemampuannya semaksimal mungkin. Pelatihan karyawan berhubungan erat terhadap hasil pekerjaan karyawan, tujuannya agar para karyawan memiliki pengetahuan, kemampuan dan keterampilan sesuai dengan tuntutan pekerjaan yang mereka lakukan. Pelatihan karyawan yang tepat, dapat memberikan efek yang baik kepada karyawan 
sehingga karyawan dapat mengembangkan diri dan mampu memahami beberapa hal terkait pekerjaannya. Pengawasan merupakan suatu kegiatan yang berusaha untuk mengendalikan agar pelaksanaan dapat ber jalan sesuai dengan rencana dan memastikan apakah tujuan organisasi tercapai dan apabila terjadi penyimpangan dimana letak penyimpangan itu dan bagaimana pula tindakan yang perlu kan untuk mengatasinya. Faktor penghambat utama tersebut dapat mengakibatkan penerapannya tidak akan efektif.

\section{SARAN}

Berdasarkan kesimpulan penelitian, disarankan manajemen perusahaan agar lebih meningkatkan dukungan terhadap penerapan dan pengembangan BIM seperti memberikan fasilitas, motivasi , pelatihan, dan pengawasan. Selain itu bagi peneliti selanjutnya perlu dilakukan penelitian analisa faktor utama penghambat penerapan BIM pada proyek konstruksi bangunan air, jalan ,dan jembatan

\section{REFERENSI}

Akhmad Riduwan (2014). "Penulisan Sumber Kutipan dan Daftar Pustakan(Tugas Akhir, Skripsi, Tesis, Disertasi, dan Artikel Jurnal) Sekolah Tinggi IImu Ekonomi Indonesia (STIESIA) Surabaya". Havard- American Psychological Association Style.

Andy K. D. Wong, Francis K. W. Wong, Abid Nadeem. (2010). Attributes of Building Information Modelling Implementations in Various Countries.

Boya Ji, Zhenqiang Qi, and Zhanyong Jin I (2014). The Obstacles and Strategy of Building Information Modeling Application in Chinese Construction Industry, International Journal of Computer Theory and Engineering, Vol. 6, No. 6, December 2014.

Dorojatun Galih (2012). Building Information Modeling (BIM)

Febriana Saputri (2012). Penerapan Building Information Modeling (BIM) pada Pembangunan Sruktur Gedung Perpustakaan IPB Menggunakan Software Tekla Structures 17

Hendrawan, Eka Prasetya (2000) .Sistem Informasi Manajemen Untuk Pengendalian Mutu Pekerjaan Konstruksi

https://en.wikipedia.org/wiki/Building information modeling diakses tgl 23 September 2016

http://www.bimhub.com/blog/challenges-bimimplementation/ diakses tgl 14 September 2016 http://www.statistikian.com/2014/03/interprestasi -analisis-faktor-dengan.html diakses tgl 10 Oktober 2016

https://forums.autodesk.com/t5/komunitasindonesia/materi-autodesk-cad-camp2015-bandung/ba-p/5612144 diakses tgl 4 Nopember 2016

Kaming, P.F, (2000), Pengaruh Teknologi Informasi Pada Manajeman Konstruksi Masa Mendatang, UAJY, Yogyakarta, 2.

Lingjie Feng, Svetlana Olbina, and Raymond Issan (2014). Implementation of Building Information Modeling on K-12.

Educational Facility Projects in Florida Rinker School of Construction Management University of Florida Gainesville.

Migilinskas Darius, Popov Vladimir, Juocevicius Virgaudas, Ustinovichius Leonas . (2013). The Benefits, Obstacles and Problems of Practical BIM Implementation. Vilnius Gediminas Technical University , Civil Engineering Faculty

Prayogo,Tonny Dwihanata (2000), Analisis FaktorFaktor Yang Mempengaruhi Terhambatnya Implementasi Sistem Informasi Berbasis Komputer Pada PT. Wijaya Kusuma Contractors Di Jakarta. Universitas Atmajaya, Yogyakarta.

Ranti Ramadiaprani (2012). Aplikasi Building Information Modeling (BIM) Menggunakan Software Tekla Structures 17 Pada Konstruksi Gedung Kuliah Tiga Lantai Fahutan IPB, Bogor.

Reza Mohandesa Saeed, Rahim Abdul, Hamidb Abdul, Sadeghic Haleh (2014). Exploiting Building Information Modeling Throughout the Whole Lifecycle of Construction Projects.

Sekarsari, Jane (2014), Sistem Informasi Manajemen - Teori dan Konsep Aplikasi pada Sektor Konstruksi, Universitas Trisakti, Jakarta. 10,58-59, 86

Yogi Agustiawan (2011), Perubahan Dalam Organisasi dalam Implementasi Sistem Informasi. Jurnal IImiah, Vol 1 , No.2

Yunfeng Chen, Hazar Dib, Robert F. Cox. (2014). A Measurement Model of Building Information Modelling 
Halaman ini sengaja dikosongkan 